УДК 821.163.41.09-1 Јеврић, Даринка https://doi.org/10.18485/godisnjak.2020.15.8

Александра 3. Миљановић* Универзитет у Београду

Филолошки факултет, докторанд
Оригинални научни рад

Примљен: 15. 09. 2020.

Прихваћен: 10. 11. 2020.

\title{
ЕСХАТОЛОШКА СЛИКА СВЕТА У ЕПСКИМ ПЕСМАМА О КОСОВСКОМ БОЈУ И ПЕСНИШТВУ ДАРИНКЕ ЈЕВРИЋ
}

Изналажењем својеврсне везе између епских песама усмене књижевности и песништва Даринке Јеврић, рад тежи да укаже на обликовање есхатолошке слике света. Есхатологија се представља у свом хришћанском значењу, онако како се обликује и у тумаченим песмама. Есхатолошка слика света уочава се у апокалиптичним визијама које и у народном песништву и у поезији Даринке Јеврић у свести призивају Косово, односно у светлом значењу визије Есхатона проистеклог из идеје васкрсења, које се твори у мотивима свесне жртве и бирања небеског царства, те мотивима манастира и фреске.

Кључне речи: Даринка Јеврић, песме о Косовском боју, епска народна поезија, есхатологија, апокалипса.

Апокалиптичне визије представљају један од основних градивних елемената од којих се твори и настаје есхатолошка слика света. У том погледу, есхатологија се, у једном од својих аспеката, образује као „учење о последњим стварима или тачније: о дешавањима кроз које ће наш познати свијет добити свој крај (...), учење о крају свијета, о његовом уништењу” (Ђого 2011: 66).

*aleksandra.miljanovic1@gmail.com 
За разлику од кружног схватања времена у најстаријем поимању света, које је присутно у старијим слојевима народне традиције, есхатолошка визија света, коју је изнедрило хришћанство, подразумева линеарно устројство времена ${ }^{1}$, које има свој почетак и свој крај оличен у фигури Христа: „Ја сам алфа и омега, почетак и свршетак, говори Господ, који јест, и који бјеше, и који ће доћи, сведржитељ" (Откривење I, 8). Стога, есхатологија као начин схватања света подразумева и историју, тј. својеврсно гледање на историју и неминовну будућност која ће уследити, при чему се Страшни суд и Есхатон уобличавају као њени последњи догађаји. ${ }^{2}$

Апокалипса је као нераскидиви део есхатолошке слике света у српским народним песмама означена синтагмом која у себи крије високи значењски потенцијал и својеврсну метафоричност - последње време. Порекло есхатолошких елемената у епским народним песмама потиче од хришћанских извора ${ }^{3}$, с тим да не треба губити из вида и везу са усменом традицијом. ${ }^{4}$

Мотив последњег времена се у епским песмама обликује двојако. Најпре, апокалиптична визија света се рађа услед „поремећене природе патријархалне тектонике свих људских односа" (Кољевић 1974: 128) и антиципирају је „нестајање добрих обичаја и побожности; тешка времена, несреће, болештине, глад и друге невоље које стижу људски род као казна за грехе" (Чајкановић 2014: 199). Песма Свеци благо дијеле управо илуструје поремећене породичне и уопште, људске односе, као и морално посрнуће, сликовито дочарано стиховима у којима Блажена Марија говори Светом Илији: У Инђији тешко безакоње: / не поштује млађи старијега,

${ }^{1}$ „Вријеме више није оно кружно Вријеме Вјечног Повратка, него линеарно, неповратно вријеме [...] Овдје се више не ради о козмичкој обнови која једнако укључује обнову једне заједнице (или свеукупности људске врсте). Ради се о суду, о избору; само ће одабрани живјети у вјечном блаженству" (Елијаде 2004: 71).

2 ,Ако човек старог века (антике) сања о повратку у изгубљени рај и о повратку универзалне хармоније после хаоса пролазног света, хришћанство поима историју као догађај божанског стварања, са почетком и са завршетком без симетрије. Историја је мост између вечности пре човековог пада и после општег Васкрсења, израз и могућа последица слободног избора у односу према Богу. Она почиње прародитељским грехом и завршава се Страшним Судом, што је резултат слободног избора. Главни догађај свега је Христово васкрсење, услов општег Васкрсења, васкрсење које ће означити крај пролазне историје” (Бојовић 2008: 51-52).

${ }^{3}$ С тим у вези, Чајкановић истиче: „С. М. Орхановић, научник истанчаног суда, претпоставио је да су првобитни извор била разна откровења, како оно Јованово, тако и остала апокрифна, а такође и византијски Физиолог, и да су отуда преузете есхатолошке представе и описи" (Чајкановић 2014: 207).

${ }^{4}$ „Веома је тешко утврдити одакле су, према томе, народне песме преузеле ове визије. Као што су могле то учинити непосредно из Библије, могле су црпети и из Палеја, летописа, хроника и из разних апокрифа, при том никад не губећи своју везу са живим токовима усмене традиције” (Милошевић Ђорђевић 1971: 178). 
/ не слушају ђеца родитеља; / родитељи пород погазили, - / ирн им био образ на дивану / пред самијем богом истинијем! - / кум свог кума на судове ћера, / и доведе лажљиве свједоке / и без вјере и без чисте душе, / и оглоби кума вјенчанога, / вјенчанога или крштенога; / а брат брата на мејдан зазива; / Ђевер снаси о срамоти ради, / а брат сестру сестром не дозива (Вук СНП II, 1). Стихови о одговору Светог Илије ${ }^{5}$ зазивају Судњи дан, те као подтекст одјекује Јованово Откривење: „И видјех у десници онога што сјеђаше на пријестолу књигу написану изнутра и споља, запечаћену са седам печата...” (Откривење $\mathrm{V}, 1$ ), након чега наступа пустош, болест и смрт, а само они који су се покајали настављају да живе: Што остало, то се покајало, / господина бога вјеровало (Вук СНП ІІ, 1). Ипак, поред хришћанског подтекста, песма Свеци благо дијеле описује и једну есхатолошку кризу „до какве нужно долази у цикличном кретању времена и која резултира обнављањем складног међусобног односа неба и земље, богова и људи; при том упоредо настаје ново, катастрофама у моралном смислу селектовано човечанство и наступа нов божански нараштај" (Лома 2002: 55).

Последње време описано је и застрашујућом сликом у којој „промене у природном поретку ствари наговештавају предстојећи смак света" (Чајкановић 2014: 201). Такву апокалиптичну визију Југ Богдан чита из књига старославних у песми Женидба кнеза Лазара: Видите ли, браћо моја красна, / видите ли како књига каже: / настануће пошьедње вријеме, / нестануће овие и вщенице / и у пољу челе и ивијета; / кум ће кума по суду ћерати а брат брата звати по мегдану! (Вук СНП II, 31).

Са друге стране, мотив последњег времена у епским народним песмама наговештава предстојећи крај историје уобличен у мотиву косовског пораза, који се у свести народног певача и колектива јавља као пропаст, смак света. ${ }^{7}$

\footnotetext{
${ }^{5}$ Молићемо бога истинога, / нек нам даде кључе од небеса, / да затворим' седмера небеса, / да уадарим' печат на облаке:/ да не падне дажда из облака, / плаха дажда, нити роса тиха (Вук СНП II, 1).

${ }^{6}$ Орхановић у овим стиховима уочава првенствено Методијево Откривење, где су описане „тужне прилике које ће насати у последњем времену кад Турци преузму царство [...] Према Сказању Методијевом Измаилћани су народ који ће гневом и јарошћу бити пуштен на земљу, и на човека, и на скоте, и на звери, и на шуму, и на воћке. Они треба да заузму сву хришћанску земљу [...] По томе је разумљиво што Југ у песми каже да ће у последњем времену нестати овце и пшенице, пчеле и цвета" (Орхановић 1934: 211).

${ }^{7}$ Тема последњег времена се непосредно везује за „косовске догађаје и историјску епоху; косовски пораз, као пропаст једног феудалног, религијског и националног света, идентификовао се са идејом пропасти света уопште и ретроспективно нашао себи оправдање.
} 
У народним песмама косовске епике Косовски бој се обликује као велика историјска разделница ${ }^{8}$ која се у свести епске песме јавља као последњи догађај историје и битка апокалиптичних размера. ${ }^{9}$, „Иеја о пропасти света из Библије, не везује се за косовске песме случајно. Она, у ствари, по мишљењима многих научника и означава крај неке важне историјске епохе.” (Милошевић Ђорђевић 1990: 36). С тим у вези, треба напоменути да је, поред идеје о Косовском боју као крају света, образоване на симболичком и метафоричком плану, идеја о смаку света постојала и у стварносној историји ${ }^{10}$ и везивала се управо за године највећег потпадања под турску власт, тј. за XV век, те није искључено да је ова идеја додатно утицала и на визију обликовану у народној традицији.

У народним песмама апокалиптичне визије јављају се као слике обавијене слутњом краја оличеног у косовској легенди, нарочито у песмама које опевају догађаје који се дешавају непосредно пред сам бој.

Песма Зидање Раванице доноси стихове у којима је апокалиптична визија обликована посредством мотива најезде Турака који пустоше земљу и светиње, а на коју упозорава Милош Обилић: настало је пошљедње вријеме, / хоће Турчи ияарство преузети, / хоће Турции брзо царовати; / обориће наме задужбине, / обориће наше намастире, / обориће иркву Раванииу, / ископаће темељ од олова, / слијеваће у топе ђулове, / те ће наме разбијат градове (Вук СНП II, 34).

Својеврсна апокалиптична слика образује се у Миличиној визији боја у којој преовладава слутња таме која све обавија (Петрановић II, 25), тј. у мотивима из Миличиног сна којима се зазива Откривење ${ }^{11}$ : Ово ми се

Одговорност пред поразом ублажавала је неизбежност наступајућих догађаја" (Пешић, Милошевић Ђорђевић 1984: 211).

${ }^{8}$ Косово је „историјска разделница на којој се читава историја разлаже на два основна времена, на време пре Косова и на време после Косова. На Косову се завршава време српске власти и слободе и почиње време српског ропства и турске владавине.” (Деретић 2000: 102).

${ }^{9}$ „Косовски пораз схваћен је апокалиптички, као погибија свих, изузев оних који су с Вуком Бранковићем срамно побегли. На бојном пољу остали су само мртви и рањени" (Деретић 2000: 248).

${ }^{10}$ „Идеја о последњем веку често је присутна у средњовековној литератури, било да је реч о византијској, словенској или латинској. Ове идеје су се у Византији појавиле у једном кратком анонимном тексту из X века [...] Један од последњих великих византијских умова, а који је вероватно био Генадије Схоларис, први патријарх после пада Цариграда, тврди да је крај света (одређен) за 1493/94. годину којом се завршава седми миленијум" (Бојовић 2008: 53).

${ }^{11}$ „И трећи анђео затруби, и паде с неба велика звијезда, која гораше као свијећа, и паде на трећину ријека и наизворе водене" (Откривење VIII, 10)

„И четврти анђео затруби, и ударена би трећина сунца, и трећина мјесеца, и трећина звијезда, да помрча трећина њихова, и трећина дана да не свијетли, тако и ноћи." (Откривење VIII, 12). 
ноћаске трудан санак изаснио, / Дје ми зв 'језде падаху с небеса на ирну земьу, / Дје ми бјеше на небу мјесеи потамнио, / И дје се је ведро небо на четверо распукнуло! (Богишић, 1). Управо ове небеске представе у фонду ониричких слика често упућују на несрећу заједнице, тј. апокалиптични догађаји на небу пресликавају се на оне земаљске (в. Радуловић 2003: 25-46).

Поетика Даринке Јеврић одликује се стварањем нарочитог односа према традицији ${ }^{12}$ схваћеној у елиотовском смислу ${ }^{13}$. Баштина коју ова песникиња бира да тематски, мотивски, стилски и лексички овековечи у својим песмама креће се у широком распону српске културе и књижевности од народне и средњовековне традиције до савремене уметности. У песништву Даринке Јеврић бројне песме настају на темељима народне уметности, те је могуће уочити паралеле између њене поезије и поезије народног певача, које се уочавају у великом броју мотива, нарочите лексике и израза које црпи из спремишта народне традиције, а које се проналазе у безмало читавом песничком опусу ове песникиње. „Песникиња користи оне симболе који чине суштину бића колективне свести српског етноса попут дома, огњишта, прага, мајке, предака, биља. Поред ових симбола песникиња користи и готове моделе из народне традиције у облику народних формула из жанра лирске песме, бајке, говорних народних творевина" (Питулић 2017: 187).

Једна од великих тема поетике Даринке Јеврић јесте Косово као мит, традиција, историја, садашњост. ${ }^{14}$ Песме које промишљају Косово и српску историју уопште, понајвише се уочавају у песничким збиркама Ижице и Хвостанска земьа, које већ самим својим насловима призивају тра-

${ }^{12}$ „Однос према традицији је кључан идентификацијски код, лична карта одређене културе, која је сврстава у озбиљне националне културе у европским оквирима" (Сувајџић 2010: 176).

${ }^{13}$ „Традиција се у елиотовском смислу може посматрати као низ изузетних креација наталожених у памћењу припадника једне културе” (Сувајџић 2010: 176).

${ }^{14}$ Треба нагласити да, како истиче Владета Вуковић, ,„родољубље и национални понос овој познатој песникињи нису вербално-декларативни. Напротив, у скоро свакој песми оваквог жанровског одређења спонтано зрачи висока свест и етика” (Вуковић 2000: 155). Такође, „песништво Даринке Јеврић, упркос дубоком респекту према миту и оданости косовском опредељењу, ипак није петрифицирано везано само за прошлост нити је конзервативно. Његова актуелност и модерност се састоји управо у лирским синтезама историјске и надисторијске пројекције света, у уроборусу феномена времена" (Андрејевић 2017: 33). 
дицију - Ижице, као последње слово црквене ћирилице ${ }^{15}$ и Хвостанска земља као синоним, тачније стари назив (Хвосно) за Метохију. Косово у песништву Даринке Јеврић постаје не само пука реминисценција на историјске догађаје и косовску легенду, већ метафорички и метафизички топоним који симболизује свевремена страдања и жртве. Стога се може истаћи да се звук дечанских звона „чује” и одзвања свеукупном њеном лириком.

Есхатолошка тема у поезији Даринке Јеврић понајвише је присутна управо у песмама које призивају Косово, а најчешће је образована посредством мотива смрти, историје и апокалипсе. Песма Срамотни печат из збирке Хвостанска земља уметнички дочарава својеврсно понављање есхатолошке слике из народне песме - апокалипса и Косово стопљени су у једну слику:

Срастао је сан; заокружио у году вијек:

Тестамент суров! Апокалипса? Рај?(...)

Над Пољем ирни се јато - згрушана душа наталожена зебња. Сврдлом видан вид.

Прљи огњени стуб. Опасује опака

хидра и ала са страшног суда Љевишке,

Девича, Дечана. Са утрина Светих

Архангела сустиже нас камење.

(Јеврић 2006: 154)

Из лирског вишегласја које се чује у песмама исте збирке, глас монахиње Варваре у песми Нијеми псалам у освит зорњача, гори патријаршијски конак доноси сведочење о „савременом” догађају који поприма апокалиптичке особине: бјеше пред јутрење све утихло, молитва / сишла с усана / у бројанице, у сан - кад бесовска сатнија / и арнаутски пукови бесе уротише се: / злобива душианска рука Проклетије саме / господару таме принесе на жртвеник. / У освит ирна зорњача! Гори капела зимска / уочи премаљећа. У небо лете минеји, / србљаци, октоиси, ивиле ирквене утвари. / Изгоре домазлук наш скромни, земно наме благо (Јеврић 2006: 159). Слична визија и слутња краја обликује се и у песми Молебан. ${ }^{16}$

${ }^{15}$ Наслов упућује на последње слово црквене ћирилице. Ипак, немогуће је не уочити извесни парадокс јер „књига, чији наслов носи име последњег слова црквене ћирилице, не представља крај већ почетак њеног лирског казивања" (Ракитић 2006: 12).

16 Заредио сам дуиу сакату за дан судњи, Господе, / склупчао трпюу; муком живом да посвједочим / могу: / копни Земьа хвостанска. У размрачје / потоюих љета најездише неки створи / што исполичари тек могли би бити по хрисовулу / тврдом (Јеврић 2006: 163). 
Апокалиптична визија страдања ће у песми Полазник постати визија Косова као пусте земље, где и мотив иконе губи своју онтолошку постојаност и додатно сведочи о пустоши и немогућности да се оствари молитва:

И ослушкујем: мук: хљеб

претворен у камен. Икону премрежила чама.

Двогубо чарање ово куда вазнесем;

по ком Оченаму, оче нам, за дом пуст да молим?

(Јеврић 2006: 164)

$$
* * *
$$

За разлику од апокалипсе као тамне стране есхатологије, есхатон као простор и време надилажења смрти (Ђого 2011: 59) у свом значењу крије и једну перспективу светлости и наде која је првенствено оличена у васкрсењу и доласку Царства Божјег. ${ }^{17}$ Управо се у поимању историје, неминовности смрти и линеарности времена, које одликује хришћански поглед на свет, крије светлост есхатологије ${ }^{18}$ и стога је циљ земаљског живота у хришћанској традицији „остварити есхатолошку вјечну садашњост, и друга начела којима се одређује карактер живота у односу на крај” (Ребић 2007: 112).

Својеврсна перспектива наде и светлост есхатона у косовској епици крију се у мотивима свесног жртвовања и бирања небеског царства насупрот земаљског, као и у мотиву задужбина/манастира. Косовски пораз „истовремено нуди и један сјајно изнађени излаз у надисторијско, духовно и уметничко, а самим тим у неосвојиво" (Милошевић Ђорђевић 1990: 36). Тако је есхатолошка визија Косовског боја у народној традицији уобличена као својеврсна представа колективне есхатологије која задобија национални карактер.

Отуда драма опредељивања за битку чини исходиште косовске епике. Она се развија у неколико варијација, у свакој од њих један од протагониста косовске

${ }^{17}$ „Исусова проповијед о доласку Царства Божјег (...) јесте проповијед есхатолошка. Идеја Царства Божјега има есхатолошки смисао, означава крај овога објективнога свијета и наступање другога, преображеног свијета” (Берђајев 2000: 176). У том погледу, „крај историје означава пролаз кроз смрт, али ради васкрсења. Есхатолошко хришћанство је хришћанство васкрсавајуће" (Берђајев 2000: 184).

18 „Хришћанство учи о избављењу човјека од власти свијета, од космичкога кружног кретања, од јерархије космичких духова и демона. У томе је јединственост хришћанске свјетлости, у томе је својеврсност хришћанске есхатологије" (Берђајев 2000: 207-208). 
драме стављен је пред исту дилему: да ли ићи у битку за коју се унапред зна да је изгубљена или избећи борбу по цену моралне деградације (Деретић 2000: 245).

Стих за крст часни крвиу прољевати / и за своју вјеру умријети (Вук СНП II, 44) тако постаје својеврсно знамење које обавија читаву косовску епику, уз Лазарев слободан избор смрти ${ }^{19}$ и небеског царства:

Ако ћу се приволети ичарству,

приволети царству земалькоме, земаљско је за малено ияарство, а небеско увек и довека.

(Вук СНП II, 45)

Градња манастира постаје један од кључних мотива преко којег се у епским песмама остварује премошћавање времена српске историје (Деретић 2000: 103). „Манастирска тема је супротна есхатолошкој теми „последњих времена” на коју упозоравају „књиге староставне”. Манастири одолевају зубу времена, као и народ и они трају после пропасти царства, дакле, и након „,пошедњих времена” схваћених у историјском смислу" (Деретић 2000: 104). Манастири се тако у народној традицији конституишу као творевине у којима се крије метафизичко и духовно, па као такве претрајавају у историји и уздижу се изнад апокалиптичних визија, што илуструју стихови Зидања Раванице у којима Милош саветује кнеза Лазара:
већ ме чу ли, славни кнез-Лазаре,
да копамо мермера камена,
да градимо иркву од камена,
и Турии ће изарство преузети
и наше ће задужбине служит
одвијека до суда божјега:
од камена ником ни камена!
(Вук СНП II, 34)

Мотив манастира се такође јавља у песништву Даринке Јеврић, нарочито у збирци Хвостанска земља, у којој су протагонисти песама монаси и монахиње (игуман Макарије, монах Јустин, монахиња Варвара, игуманија Параскева) чији се глас у песмама чује из манастира који

${ }^{19}$ „Слободан избор смрти постаје овде, као и иначе у великим трагедијама, последња и крајња потврда вредности живота, осведочење и залог људске слободе која се не може заувек скршити. Тако срце косовске легенде говори да живети људски живот значи и бити спреман на умирање - а то је она крајња песничка, како национална тако и лична, порука косовског мита" (Кољевић 1974: 167). 
истрајавају у историји изнова пролазећи кроз претње. Њихови монолози осликавају свевремено присуство смрти и спремност на жртву, те очекивање „небеског царства” у трпљењу и животу кроз Христа, јер управо „сва есхатологија поучава да човјек мора прећи границу овога видљивога свијета потпуно просвијетљена ума, очишћена срца, сав прерађен и усавршен светим јеванђељским врлинама" (Ребић 2007: 112).

У поезији Даринке Јеврић проналази се још један мотив који има својеврсно метафизичко значење, значење трајања и вечности, а то је фреска која се лајтмотивски прожима кроз већину њених песничких збирки где има „не само симболичко, већ суштинско значење, утемељено у вертикалној повести српске културе" (Ракитић 2006: 5). Фреска ће се нарочито пронаћи и у стожеру мотива заједно са мотивима летописа, дијака, зографа, палимпсеста, летописа и споменика, преко којих се успоставља својеврсни дијалог и веза са прецима, историјом и традицијом. Фреска је у њеној поезији примарно извор светлости која врхуни над тамом садашњег и будућег зла. У песми Фреска лирски субјекат се обраћа истој: склопиш ми руке у молбу / у јеиај у хвала / стољетьу љепоту ми у свјетлост кујеш (Јеврић 2006: 31), док дечански летописац у истоименој песми казује: ал наизуст знам: неопозив је биљег мој / трајање фреске (Јеврић 2006: 123), где се фреска проналази као залог сведочења и посредник између прошлости и онога који прошлост чува и тумачи, те постаје симбол трајања и разлог чувања сећања.

Поред тога што мотив фреске означава непропадљивост, трајање и вечност у сфери духовног и религијског, фреска се у поезији Даринке Јеврић јавља и као симбол непропадљивости и трајања у погледу стваралаштва и уметности (збирка Преварени тишином). Глас лирског субјекта у ненасловљеној песми (Јеврић 2006: 51) речју (песмом) претаче у слику (фреске) настојећи да досегне до оне димензије трајања која остаје и после уметника, јер ,има неког метафизичког проклетства у уметничкој истини да се вечност може одржати само елиминацијом живог: мртве творевине надживљују живе ствараоце" (Глушчевић 196?: 6).

$$
* * *
$$

Пажљиво читање песама изнедрило је својеврсне везе које се проналазе између тумачених тесктова усмене и писане књижевности. Поезија Даринке Јеврић тако представља сведочанство неговања културе палћења, у којем се успоставља нарочита веза са народном традицијом. 
Напослетку и у духу теме овог рада, треба истаћи и есхатолошки аспект самог стваралаштва: „Стваралаштво је у своме праизвору скопчано са незадовољством овим свијетом. Оно јесте крај овога свијета, - y своме праизворном пориву оно хоће крај овога свијета: оно јесте почетак другога свијета. Према томе, стваралаштво је есхатологично" (Берђајев 2000: 162). У том погледу, стваралачки акт и народног певача и песникиње има есхатолошки какрактер, јер симболично означава крај таме и појаву светлости, коју доноси реч.

\section{ИЗВОРИ}

Богишић: Народне пјесме из старијих, највише приморских записа, сабрао их и на свијет издао Валтазар Богишић, Биоград, 1878. Горњи Милановац: Лио, 2003.

Вук, СНП ІІ: Српске народне пјесме, скупио их и на свијет издао Вук Стеф. Караџић, књ. II, у којој су пјесме јуначке најстарије, Беч, 1845. Српске народне пјесме II, Београд: Нолит, 1975.

Јеврић 2006: Д. Јеврић, Псалам бездомника и друге песме, Приштина: Панорама.

Откривење: Откривење Светога Јована Богослова у: Нови завјет, превео Вук Стефановић Караџић, Беч, 1847. Нови завјет, Београд: Нолит, 1975.

Петрановић, II: Српске народне пјесме из Босне и Хериеговине. Епске пјесме старијег времена. Сакупио Б. Петрановић. Књига друга (1867). Приредио Н. Килибарда. Сарајево: Свјетлост, 1989.

\section{ЛИТЕРАТУРА}

Андрејевић 2017: Д. Андрејевић, „Лирске синтезе у поезији Даринке Јеврић” у: Даринка Јеврић: архетип, љубав, трагика: (тематски зборник поводом седамдесет година рођена и десет година од упокојења песникиње Даринке Јеврић, ур. Даница Андрејевић и др., Косовска Митровица: Филозофски факултет Универзитета у Приштини, стр. 23-35.

Берђајев 2000: Н. Берђајев, Опит есхатолошке метафизике, Београд: Богословски факултет Српске православне Цркве.

Бојовић 2008: Б. Бојовић, Историја и есхатологија: из историје и књижевности јужнословенског средњег века, Врњачка Бања: Братство Св. Симеона Мироточивог.

Вуковић 2000: В. Вуковић, Критичка суочавања, Врњачка Бања: Народна библиотека „Др Душан Радић”. 
Глушчевић 196?: З. Глушчевић, „Поетични живот фресака” у: У време несигурно: поезија инспирисана фрескама, Београд: Ревија.

Деретић 2000: Ј. Деретић, Српска народна епика, Београд: Филип Вишњић.

Ђого 2011: Д. Ђого, Христос, Митос, Есхатон: једно православно читање Рудолфа Бултмана и Јиргена Молтмана, Београд: Православни богословски факултет.

Елијаде 2004: М. Елијаде, Аспекти мита, Загреб: Деметра.

Кољевић 1974: С. Кољевић, Наш јуначки еп, Београд: Нолит.

Лома 2002: А. Лома, Пракосово: словенски и индоевропски корени српске епике, Београд: САНУ, Балканолошки институт.

Милошевић Ђорђевић 1971: Н. Милошевић Ђорђевић, Заједничка тематско-сижејна основа српскохрватских неисторијских епских песама и прозне традииије, Београд: Филолошки факултет.

Милошевић Ђорђевић 1990: Н. Милошевић Ђорђевић, Косовска епика, Београд: Завод за уџбенике и наставна средства.

Орхановић 1934: С. М. Орхановић, Један есхатолошки мотив у старој косовској поезији у: Прилози проучавању народне поезије, год. 1, бр. 1 (1934), стр. 208-214.

Пешић, Милошевић Ђорђевић 1984: Р. Пешић, Н. Милошевић Ђорђевић, Народна књижевност, Београд: Вук Караџић.

Питулић 2017: В. Питулић, „Традиционални симболи у поезији Даринке Јеврић” у: Даринка Јеврић: архетип, љубав, трагика: (тематски зборник поводом седамдесет година рођена и десет година од упокојења песникиґе Даринке Јеврић, ур. Даница Андрејевић и др., Косовска Митровица: Филозофски факултет Универзитета у Приштини, стр. 187-199.

Радуловић 2003: Н. Радуловић, Симболични снови у усменој епищи у: Књижевна историја, год. 35, бр. 119 (2003), стр. 25-46.

Ракитић 2006: С. Ракитић, „Од монолога до вишегласја или опора лирика Даринке Јеврић” у: Псалам бездомника и друге песме, Приштина: Панорама, стр. 5-24.

Ребић 2007: Ч. Ребић, Историјска свијест и есхатолоике теме, Приштина: Институт за српску културу.

Сувајџић 2010: Б. Сувајџић, Певач и традиција, Београд: Завод за уџбенике.

Чајкановић 2014: В. Чајкановић, „Представе српских епских песника о смаку и обнови света" у: Из српске религије, митологије и фолклора: изабране студије, Београд: Evro-Giunti, 196-213. 
Aleksandra Z. Miljanović

\section{ESCHATOLOGICAL IMAGE OF THE WORLD IN EPIC SONGS ABOUT THE BATTLE OF KOSOVO AND THE DARINKA JEVRIĆ'S POETRY}

\section{Summary}

By finding a specific connection between the epic songs and the poetry of Darinka Jevrić, the paper seeks to demonstrate the forming of the eschatological image of the world. The eschatology is presented in its christian context, the same way it is formed in the analyzed poems. The eschatological image of the world is recognized in the apocalyptic visions that are both in the folk tradition and Darinka Jevrić's poetry bringing the image of Kosovo in mind, and in the light meaning of the Eschaton's vision which comes from the idea of the resurrection, which is being created in the motifs of the conscious sacrifice and choosing the kingdom of heaven, and the motifs of the monastery and the fresco.

Key words: Darinka Jevrić, epic songs of the Kosovo battle, epic folk poetry, eshatology, apocalypse. 